\title{
The Industrial Monuments Route of the Silesian Voivodeship as an example of the regional tourism product enhancing tourism competitiveness of the region
}

\author{
Anna Staszewska, Michał Żemła / e-mail: annastaszewska@interia.pl, michalzemla@gazeta.pl \\ Tourism Department, Katowice School of Economics, Poland
}

Staszewska, A., \& Żemła, M. (2013). The Industrial Monuments Route of the Silesian Voivodeship as an example of the regional tourism product enhancing tourism competitiveness of the region. Czech Journal of Tourism, 2(1), 37-53. doi:10.2478/cjot-

2013-0003

\begin{abstract}
The paper deals with the idea of destination competitiveness and its relations with competitiveness of spatial tourism products and competitiveness of entities catering tourism in the region. The case study method is used in the paper and the example of Industrial Monuments Route of the Silesian Province is analysed. The Route is a tourist product which presents the major and most interesting industrial facilities in the Silesian Region in terms of tourist, historic and architectonic values. The creation of the new spatial product - the Route by the regional authority - enhanced competitiveness of the Province as the image was improved, as well as a competitive advantage of operators of attractions within the Route was built. Some difficulties and challenges of such a way of enhancing destination competitiveness are discussed in the text.
\end{abstract}

\section{Keywords}

Destination competitiveness, destination product, industrial tourism, Silesian Province, Industrial Monument Route

JEL classification: O14, O18, R23 / Accepted: 10 June 2013 


\section{Introduction}

Tourism is perceived as an important factor of the regional development and possibilities of development of tourism product are sought by many municipalities, regions and countries. However, the international tourism market is becoming more and more competitive. As a consequence, one can also observe a growing interest in the concept of competitiveness in tourism. At the heart of this concept there is the idea of tourism destinations competitiveness. That is because of the nature of competition on tourism market where competition between companies has secondary character to the competition between destinations (Go \& Govers, 2000, p. 79) as tourists tend to choose their destination first and then look for suitable services and goods.

The way of building up a competitive destination product is difficult due to the necessity of acknowledging and coordinating of actions of many differentiated entities. The task becomes even more challenging when taking into the consideration the regional product. Among the reasons even a bigger number of entities involved and participation of both local and regional public bodies might be stated. On the other side, such an approach gives bigger possibilities of creation of projects which can involve big areas, such as tourism routes. All those challenges and opportunities are not presented clearly in the literature. The paper is aimed at an analysis and discussion of some of them, illustrating the example of the Silesian Province in Southern Poland. The analysed example is taken from the Industrial Monuments Route of the Silesian Province which is declared to be the most interesting route of industrial tourism in Poland. Both involvement and actions of the regional authorities and attraction operators are presented in order to show how competitiveness of a single attraction - and of the entity running it - and competitiveness of the region are interlinked.

\section{Theoretical basis}

While many destinations engage in tourism promotion, a much lower proportion of them focus their attention on the development and delivery of the various attractions and activities that make up the tourism product. The fact is, though, that unless the tourism product meets the needs and expectations of tourists, the destination cannot realize its full potential. Tourism products are the basis for a destination tourism sector operation. Unless the product offer is indigenous and appropriate for the region or country, while also meeting ever changing customer needs, marketing alone will not achieve the destination potential. The range and calibre of the tourism product offering is what attracts tourists to a destination (UNWTO, 2011).

The number of studies published on the destination marketing and management has grown considerably in recent years; indeed, it can be argued that there is now a substantial body of academic work in this area (Bornhorst, Ritchie \& Sheehan, 2010). The body of research focusing on destinations has recognized for long that the destination is not only the primary arena for tourist consumption (e.g. von Friedrichs Grangsjo, 2003; Fyall, Garrod \& Tosun, 2006) but also comprises a complex web of inter-organizational 
supply relationships (Buhalis, 2000; Sautter \& Leisen, 1999). As Manente and Minghetti (2006) point out, a destination is essentially a group of actors linked by mutual relationships with specific rules, where the action of each actor influences those of the others so that the common objectives must be defined and attained in a coordinated way (Fyall, Garrod \& Wang, 2012). Yet, the development of tourism products is a part of a large, inter-linked and continuing process and should not be considered in isolation (UNWTO, 2011).

As Ritchie and Crouch (2005) and Vanhove (2005, p. 108) effectively point out, the fundamental product in tourism is the destination experience. For most tourists this experience takes place in a rather small geographic area. Competition, therefore, centres on the destination (d'Angella, De Carlo \& Sainaghi, 2010, p. 61). The term destination competitiveness is developed from the ideas taken from both regional sciences and strategic management (Ritchie \& Crouch, 2005). Most of up-to-date studies on strategic management and competitiveness of tourism destinations are based on well-known strategic approaches: industrial organization (IO) and resource-based view (RBV) or their combinations (Flagestad \& Hope 2001; Dwyer \& Kim, 2003). However, changes in global business, such as melting companies' boundaries or establishing strong non-competitive relations with other market participants enhanced the development of new models originating from inter-organizational relations theory (IR), transaction costs economics, relationship marketing and network analysis. Following some of the fundamental studies (Fyall \& Garrod, 2005; Wang \& Xiang, 2007; Beritelli, Begier \& Laesser, 2007), this paper is based on the assumption that the tourism industry is a network industry par excellence (Scott, Cooper \& Baggio, 2007, p. 7) and the concept of IR allows to explain best the phenomena taking place in a destination, including destination competitiveness. No single company on the tourism market has the possibility to fulfil all tourists' needs. Tourists during their stays at the destinations use services of many companies as well as public services. Also the main reason of tourists' stay at the destination is usually not the use of a company's services. Non-competitive relations between the closest competitors are necessary. The main source of competitive advantage is recourses, such as in the RBV. However, these are usually the resources, which are external to the company and the non-competitive relations are established to create company's access to those resources. This includes also public services and free resources, such as landscape or climate which are directly connected to a given location.

The enhancement of tourism destination competitiveness is a complex and difficult task not only because of the issues with theoretical description of the phenomenon. The tourism destination is a complicated entity with very limited possibilities of governance. There are many independent stakeholders being involved in the process of destination product creation and there are usually no hierarchical links between them. A stakeholder is any individual, community, group or organization with an interest in the outcome of an activity, either as a result of being affected by it or by being able to influence it (Freeman, 1984; UNWTO, 2010). Those stakeholders in a destination represent both public and private sector. Middleton and Hawkins (1998, p. 87) number four major groups of stakeholders in a destination: inhabitants, local and regional authorities' representa- 
tives, tourism enterprises and visitors. Similarly, UNWTO (UNWTO, 2010, p. 4) manual states that stakeholder bodies may fall into one of three overall types: government or public sector, including national and local government and official/state agencies, business or private sector including enterprises of all sizes, from multinationals to SMEs, engaged in commercial activity, and civil society which is loosely defined as occupying the area between the above two, and includes voluntary organizations, NGOs, religious or educational bodies. The creation of a competitive offer then needs acknowledging and understanding of aims of individual stakeholders and sound leadership replacing hierarchical linkages, known from the corporate management theory. In this context we often talk about destination governance, not the management, which is based on a multi-stakeholders approach. The multi-stakeholder approach is defined as an action that involves more than one type of stakeholders with different core purposes and overall interests although their interests may coincide or be mutually supportive in terms of the specific collaborative action (UNWTO, 2010, p. 4). The key factors of effectiveness of the multi-stakeholders approach are destination leadership and partnership.

The paper presents the idea of the multi-stakeholders approach to tourism product development in regard to a specific kind of tourism destinations, i.e. the industrial tourism area. This kind of tourism is rather a new phenomenon and its fast development is stimulated both by the growing demand and by the social value added to the supply side which is connected with the preservation of heritage items. The development of the idea of industrial heritage is strictly connected with the history of 20th century. Entire regions connected with heavy industry went into an economic crisis: in Germany the Ruhr district and Saarland, in Great Britain Wales and the Mid West, the industrial centres of Belgium, as well as the industrial regions in the North of France and Lorraine. Enterprises were closed or pooled, hundreds of thousands people lost their workplace. The industrial sites were mostly demolished, machinery was scrapped. Only a few outstanding technical artefacts have remained unchanged. They are the focus of the preservationists and form the framework of the European industrial heritage. The concept "industrial heritage" stands for the preoccupation with the complete history of civilization of the industrial age: Facets of the industrial heritage are the history of technology, the social history of the work, the architecture history of the production centres as well as the dwellings of the entrepreneurs and of the workers, the development of the geographical space ("industrial land developed and cultivated by man") (Backes, 2008).

Preservation of the first relics of the industrial heritage started in the $1970 \mathrm{~s}$. The first settlements were classified as historical monuments. These were housing estates, in which the employees lived. These places got to be witnesses of many generations of industry workers and their families. Later on, industrial plants, machinery and factory buildings were used as museums or venues or simply only as landmarks of the industrial history. Within the following years, a further aspect of these relics occurred: They created a touristic potential for the falling regions of the coal and steel industry - routes of industrial heritage and networks of the industrial heritage arose (Backes, 2008). 


\section{Methodology}

The paper is based on the well-known method which is the case study analysis. The case study is a research strategy which focuses on understanding dynamics, present within single settings (Eisenhardt, 1989). The case studies may involve either multiple or single cases, and numerous levels of analysis (Yin, 1984). In the presented paper different levels of analysis are connected with different approaches to network analysis. A social network is basically a set of actors and relations that hold these actors together (Emirbayer, 1997). The actors can be individuals or aggregate units, such as departments, organizations, or families. The actors form social networks by exchanging one or many resources with one another. Such resources can be information, goods, services, social support or financial support. These kinds of resource exchanges are considered a social network relation, where individuals who maintain the relation are said to maintain a tie (Chung, Hossain \& Davis, 2005).

The network approach emphasizes three basic aspects: nodes, ties between the nodes and network configuration. The nodes are the network's actors. The ties pertain to the contacts made between the nodes. They include an exchange of tangible and intangible resources and any contacts made to enhance the effectiveness of the individual actors as well as the network as a whole. The network configuration is comprised of a system of relationships and the typology of the actors' roles and positions as well as properties of the entire network. The configuration of nodes arises from the number and diversity of actors, the content of the relationships between them, the alignment of their interests and their roles in creating a common output (Żabińska \& Maciąg, 2013).

There are two overarching approaches which characterize the social network analysis. The whole network analysis looks at the network from the outside, with all the data that one chooses to collect on each tie and each node. The personal or egocentric network analysis looks at the network from the inside, with all the data that one chooses to collect on one node and its ties (Williams \& Durrance, 2008). The scope of the analysis is wide and includes the level of the Industrial Monuments Route as a whole - which is the consequence of the implementation of the whole network approach (Kilduff \& Tsai, 2003) - and the level of single attractions on the Route. It has been argued that the whole network approach is not enough to capture the contextual elements that condition the governance (Ysa, Curtó \& Esteve, 2009). On the level of the Route (the whole network approach), the actions of the regional authorities which are the Route creator are studied and on the level of the single attraction, the chosen monuments and their benefits are discussed. The fact that they differ substantially regarding their operators, way of creation of tourism experience, or history is important for the analysis. The information used in the analysis is taken from official documents of the regional authorities and the attraction operators as well as from the unofficial meetings with representatives of those entities. The aim of the presented analysis is an investigation of aims and benefits obtained by the individual Route (network) members, as well as problems experienced by those stakeholders. Methodologically, there were used different approaches to network analysis. 


\section{Results and Discussion}

\section{Presentation of the Industrial Monument Route of the Silesian Province}

Owing to the dynamic growth of industry as well as the application of the most up-to-date achievements of technology, the Upper-Silesia became known in the whole Europe at the turn of the 18th century. This part of Silesia has always been associated with a large number of industrial plants and factories, as well as vast amounts of dust and pollution. Currently, the borders of the Silesian Province include former provinces of Częstochowa, Katowice and Bielsko-Biała. This has been one of the most industrialized regions in the world. The tourist product of the region is related to distinct sightseeing values, resulting from the dense concentration of the objects of material culture. The Silesian Province has got a big number of the catalogued resources of industrial heritage, which include 1621 objects, 149 of which have been registered as monuments. There are 860 historic objects related to mining industry. The Industrial Monuments Route is a theme, a car based tourist trail of a regional scope, including objects connected with the industrial heritage of the Silesian region. It is composed of 36 facilities associated with the traditions of mining and metallurgy, electricity generation, railways, communications, production of water and the food industry. The project has been managed by the Regional Promotion, Tourism and Sport Department of the Marshal Office of the region of Silesia. The Silesian Cultural Heritage Centre in Katowice and the Silesian Tourist Organization also participated in the creation process. The Managing Committee of the region of Silesia with resolution no. $1153 / 268 / \mathrm{II} / 2005$ of the 21st of June 2005 determined the list of objects included in the newly created regional tourism product, called "The Industrial Monuments Route of the Silesian Province" and secured the financial resources for the undertaking of the project. The map of the Route is presented in Figure 1.

The Industrial Heritage Promotion Section of the Department of Economy, Promotion and International Cooperation of the Marshal Office of the Silesian Region is currently a coordinating (managing) unit of the Industrial Monuments Route. The tasks that are carried out by this unit include:

- preparation (in cooperation with the external units) and implementation of the provisions of the strategic documents which determine the directions of the product development;

- monitoring the process of trails and sites signs and its update. The signing system includes: road signs on the route trail (the task carried out by the Silesian Tourist Organization), informational boards situated by the sites, "membership certificates" signs at the sites and stands with mini cards that advertise all the sites on the route;

- gathering (and auditing), preparing, processing, updating and distributing information about the entire route, individual sites and their offer, promotional activities and events that are being organized within their premises, consequently coordinating the activity of all sites that belong to the route. Approximately, every two years the update of the route membership is carried out;

- control over individual elements of visual identification of the product; 
Figure 1 The map of the Industrial Monuments Route of Silesian Voivodeship

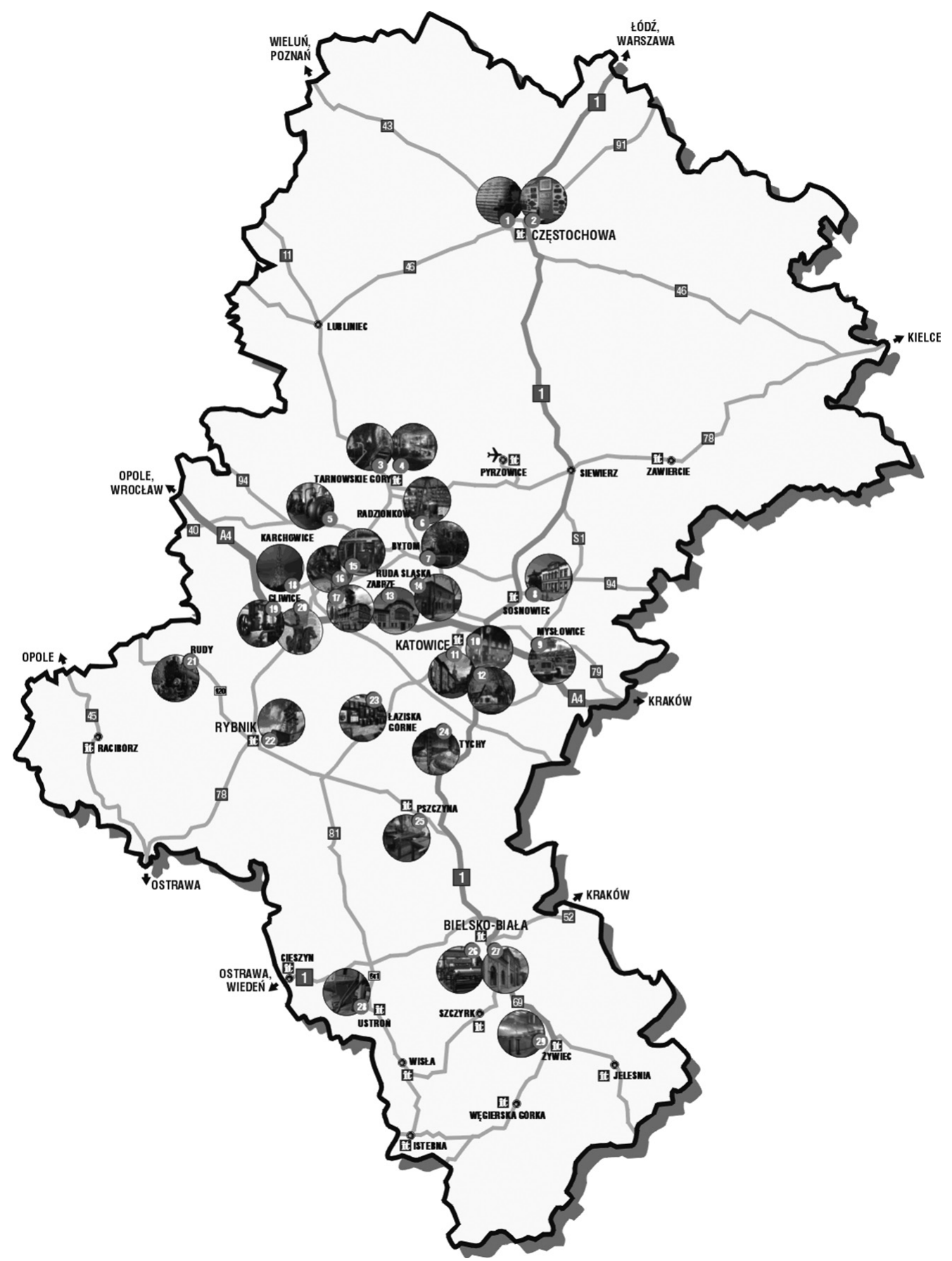

Source: www.zabytkitechniki.pl 
- organization of promotional activities, which include a commission of the organization of comprehensive promotional campaigns during which a variety of marketing communication activities, i.e. above the line and below the line activities as well as public relations actions are carried out;

- coordination of the events organized on the Route, and especially the organization of "Industriada - the feast of the Route" - the main marketing event of the year (promotion and organization of this event on the voivodeship level is commissioned by the marketing agency selected by the Marshal Office via tender procedure);

- internal marketing - organization of trainings and workshops for the owners, managers and personnel of the sites that belong to the Route in order to upgrade the quality of the provided services;

- organization of complex services, e.g. preparation of a joint offer of thematic classes that may be conducted at the sites which belong to the Route;

- commission of the study on the volume of visitors on the route and their preferences (this task is carried out in cooperation with the Silesian Tourist Organization).

The establishment of the Industrial Monuments Route and its management is solely financed from the self-government budget of the Silesian Voivodeship. Since its opening for the tourists in autumn 2006 till the first half of 2012, the expenditure for this purpose reached 11 million PLN. Moreover, the sites of the Route were granted over 31 million PLN from the Regional Operational Program for the Silesian Voivodeship for 2007-2013, for the development of tourist infrastructure and offer (Hajduga, \& Staszewska, 2013).

The intention of the project authors is from the historical and architectural point of view to construct a high-quality tourist product on the basis of the most important and most interesting industrial objects in the region. It is intended that the Industrial Monuments Route of the Silesian Province should be the most interesting industrial tourist Route in the country. Furthermore, as one of the main tourist products of the region of Silesia, it should characterize the region on the tourist maps of Poland and Europe. The number of visitors on the Route is steadily growing and exceeds annually 0.5 million of tourists (Table 1).

Table 1 A number of visitors on the Industrial Monuments Route in recent years

\begin{tabular}{|l|c|c|}
\hline \multicolumn{1}{|c|}{ Year } & Number of visitors & Annual growth of number of visitors \\
\hline 2009 & 468,000 & - \\
\hline 2010 & 502,000 & $7.2 \%$ \\
\hline 2011 & 537,000 & $7.0 \%$ \\
\hline 2012 & 581,000 & $8.2 \%$ \\
\hline
\end{tabular}

Source: Hajduga \& Staszewska, 2013

The Industrial Monuments Route of the Silesian Province has been created by joining a couple of dozen objects. Its intention is to create a new value. In that respect the preparation of a complex offer is superior to single services. The Route reveals the 
character of the Region that constitutes its wealth and it is the basis of its identity. It may be a unique sales proposal of the Silesian Province. This tourist product has been awarded many times. In 2008 it was awarded the Golden Certificate of the Polish Tourism Organization for the best tourist product in the country. In January 2010, as the only route from Central and Eastern Europe, it joined the European Route of Industrial Heritage - ERIH. In October 2010, the Route was awarded the Gold Medal of the Poznań International Fair for the best tourist product in Poland. The preparation of the Route assumes that the Route is to be the element which will integrate and activate the whole Province.

\section{Tourism attractions on the Route - chosen examples}

Below a few of the most important monuments are presented. The aim of this presentation is to emphasize the differences between them, regarding their ownership, market aims and the nature of the offered experience.

Tyskie Browarium is a museum institution opened in 2004 with a collection of exhibits that focus on the tradition and the over four-hundred-years-old history of the Tychy Duke's Brewery. At the end of the 20th century, when the Tychy Brewery became part of Kompania Piwowarska SA - one of the largest brewery group in Poland owned by SAB company - the first guides were provided to serve the visitors, and in 2003 the brewery tour offer was officially launched. The tour of the Tyskie Browary Książęce has quickly become very popular. Today, it attracts ca. 2000 visitors a month.

Tyskie Brovarium is located in the building of a former Evangelical chapel which was built in 1902. It features a collection of exhibits related to the craft of brewing beer, which is also served, as well as the tradition and the history of Tyskie Browary Książęce. The items in the exhibition include beer jugs, pouring accessories, barrels, corks, crown caps, labels, coasters, cooper's tools and other antique and modern items. Tyskie Brovarium is a combination of tradition and modernity, which is clearly visible in the manner in which the exhibition is organized. Guests are welcomed by a Prince from a mysterious painting. The collection is accompanied by multimedia attractions, including a cinema and an interactive barrel. The 3D film shows the history of the brewery; the guests can send an electronic postcard from the barrel and test their knowledge in a beer quiz. It is also possible to play games on touch panels.

Tyskie Brovarium belongs to a big beer producer and it is treated by the owner as a way of promoting its products rather than the tourism attraction. For the first few years the entry to Brovarium was free of charge and now the ticket price (about 3 Euro) is still low since the tourism is not the most important function of this museum.

The emergence of the mine "GUIDO" was associated with the XIX century industrial revolution in Silesia. The exhibition function of this place begins in 1967 when the Experimental Coal Mine M-300 was established and then in 1982 the Guido Mining Heritage Park begins its operation but, unfortunately, in 1996, it ceased its activities. Eleven years later the "Historic Coal Mine GUIDO" opened its doors to tourists again. Its attractiveness for tourists is connected with the fact that there is the deepest tourist route 
in a coal mine in Europe. In its natural scenery, visitors may discover what every day work of miners was like and how the equipment used for coal mining changed over time. The visit is accompanied by impressive sound and light effects. Apart from visiting opportunities, the "Guido" mine provides original artistic sensations. Its flagship products include, for example, Muzyka na Poziomie (Music event) and Teatr na Poziomie (theatre event) - periodically held events, benefiting from the exceptional atmosphere of the underground chambers. The operation of Guido is strongly supported by the municipality of Zabrze, labelling itself the capital of industrial tourism. Nikiszowiec settlement in Katowice constitutes a substantially different kind of tourism attraction than other elements of the Industrial Monuments Route described here. Being a settlement, not a single facility, it has no owner or directly managerial body. It is located in the municipality of Katowice and the local authority of this city takes on the responsibility for the state of this settlement. The settlement Nikiszowiec was built at the beginning of the 20th century, according to the project of Georg and Emil Zillmann. It embraced apartment buildings for 642 families, Catholic church, schools, sewers, roads and water supply. The whole architecture premise as well as individual buildings has been preserved in a good shape until today. They offer tourists well isolated and internal concentrated and cohesive settlement of industrial workers from the beginning of the 20th century. Nowadays, it comprises 9 compact building quarters connected by means of characteristic batten plates and the parish church of St. Ann from 1927. The settlement was a background for many movies about Upper Silesia.

The Black Trout Adit is a fragment of the longest drift in the network of lead and silver mines in Tarnowskie Góry. It is a unique, 600-meters part of the 19th century Fryderyk mine. The Black Trout Adit was drilled until 1935. The excavation was cut in the dolomite rock, in the place where clay or quick-sand was found. A 600-metre-long fragment is available for the public at the depth of 20-30 meters between the drifts Ewa and Sylwester. The tour is conducted in boats and it is the longest underground tour done by boats in Poland. The Black Tout Adit belongs to the Association of Friends of the Tarnowskie Góry Area (pol. Stowarzyszenie Miłośników Ziemi Tarnogórskiej). This Association also operates Historic Silver Mine in Tarnowskie Góry and Tourist Accommodation House Gwarek.

\section{Benefits and problems perceived at the level of the Route - the whole network approach}

The idea of building tourism attractiveness of the Upper Silesia region on the bases of post-industrial heritage remains controversial. Firstly, it is the image problem. The industrial landscape and architecture have been perceived as an important weakness of the region since many years. Now it is supposed to be the most important feature which attracts tourists. The task is even more difficult, taking into the consideration that many of interesting post-industrial objects are in extremely bad shape. However, the regional experience with similar historical background from Germany, Great Britain, Belgium and other countries show that such a change of perception is possible and the 
post-industrial tourism gains tourists' interest. Another problem is a creation of holistic product. In "typical" tourism places this is based on the cooperation between public authorities and private companies which offer services and tangible products for visitors. Considering the views presented in literature (Jamal \& Getz, 1995; Hall, 1999; Roberts \& Simpson, 1999; Żemła, 2008), which establish such cooperation and develop partner relationships between the entities is a challenging task. However, in the case of the Silesian Province and its Industrial Monuments Route, the situation is even more complicated. The regional authorities, leaders in the process of creation of the Route had to work with the local authorities of many different places as well as with the operators of potential attraction included to the Route. Those operators are substantially different than the typical tourism industry companies in a tourism destination, which is usually dominated by SMEs private companies. In presented examples, no single attraction is run by a private commercial tourism company, which remains truth also for most of other attractions on the Route. Working with associations, municipalities and even big commercial companies, but representing other industries (like brewery), needs acknowledging and acceptation of their aims which are much more diversified and usually not concentrated on business success on the tourism market. However, enhancing the nonbusiness-oriented entities to cooperation might be a bit easier since they do not tend to treat one another as enemies as it happens among competing companies, especially the small ones (Simpson \& Bretherton, 2004, p. 112).

Despite the issues described above, it is possible to state that the Industrial Monuments Route is already an established product. It is has not been probably finished yet, but definitely established. It is a good time to make the first analysis of competitiveness of this product, including the whole Province and individual attractions and also of how those three are interlinked.

Considering the Route, supported with a strong advertisement campaign inside and outside the Province, it has become one of the most recognizable tourism product of that region. The campaign directed inside is important because all attractions on the Route have to attract the Province inhabitants first. And it was not so for many years. Oppositely, tourists coming from the outside of the region usually appreciate the offer, but they have to come to the region which has not been perceived as an attractive one for decades. After establishing some level of perception of tourism attractiveness of the Route, the next step has to be to ensure a higher economic effect which is possible only by including more additional services for tourists - accommodation, gastronomy, or souvenirs. At this moment it is one of the most important weaknesses of the whole Route. It lowers visitors' satisfaction; for example, they have very limited possibilities to have their lunch when visiting Nikiszowiec. But also this causes that visitors do not spend their money during their visit and the economic effect reached by the Province and by the municipalities is very low. A very important aspect for changing this situation is the development of travel agencies' offer connected with the visit of post-industrial attractions of Silesian Province. At this moment two travel agencies - Abraksas and SilesiaTrip.pl offer complex tours, including all required fees, transportation, expert guides and tour leaders if necessary. Both companies cater organized groups as well as individual tour- 
ists, which is important owing to a low level of the development of additional services connected with the attractions.

\section{Benefits and problems perceived at the level of individual attractions - the egocentric network approach}

Another issue is how individual attractions profit from their membership in the Route. Definitely, the Route managed to achieve the effect that was not possible for the separated attractions. This is mainly the case of recognition and perception. The Route presents the density of attractions in the area and has a much wider opportunity, such as organizing promotional actions, changing small, local, often forgotten attractions into Province hallmarks. Also new attractions were introduced to the tourism market which would not happen without the hallo effect induced by the Route. This introduction to the tourist market was probably the only chance for many post-industrial objects to survive as they were originally in a very poor state. This is probably the case of the Guido coal mine and Narrow-Gauge railway.

\section{Mixing the perspective - an event as a tourism product combining the potential of individual members and the Route as a whole}

Turning post-industrial objects and landscapes into tourist attractions changes the image of the Silesian Province. But the process is much longer and still ongoing. The Province authorities understand this link and, apart from the promotional support, they are looking for new options of increasing attractiveness of the Route and individual attractions. Probably the most spectacular result of this search is an establishment of a new event connected with the Route called Industriada. Industriada is a one-day festival held annually on the second Saturday of June. So far, there have been three years of the event. This is a large-scale event in which all facilities of the Industrial Monuments Route are engaged. The organizers are the Marshall Office of the Silesian Province, operators of the attractions on the Industrial Monuments Route, local governments and non-governmental organizations. The most important effect of the event is "putting more life" into the attractions. This effort might be illustrated in numbers of 2011: over 53 participants in 150 events lasting all together over 350 hours. The programmer of "Industriada 2012" encompassed 228 events held at 37 sites, 32 of which belonged to the Route and were organized in 22 cities of the Silesian Voivodeship. Over 62 thousands of people took part in "Industriada", that is 8 thousand more than in the second year of the Route's feast, and 33 thousand more than during the first year of 2010 (Hajduga \& Staszewska, 2013)

Voivodeship self-government's expenditure for "Industriada 2012" amounted to around 2.5 million PLN and included:

- costs of hiring the advertising agency which was responsible for promotion and coor- 
dination of the Route's feast (promotional activities included: advertising, sales support via direct marketing events and public relation activities) - 1 million PLN;

- costs of the broadcasting time and blocks of advertising space purchase -0.75 million PLN;

- costs of direct grants for 12 non-governmental organizations for the preparation of individual events during the festival (grants are awarded through competition procedures and can cover up to $50 \%$ of the entire cost of the given project) -0.5 million PLN, promotional costs of the festival (for example: organization of an exhibition at Zollverein complex in Essen associated with the cooperation with "ExtraSchicht", publication of the Route's guidebook, trainings, workshops and study tours) - 0.25 million PLN.

Figure 2 Organization model of Industriada

Silesia.Positive energy
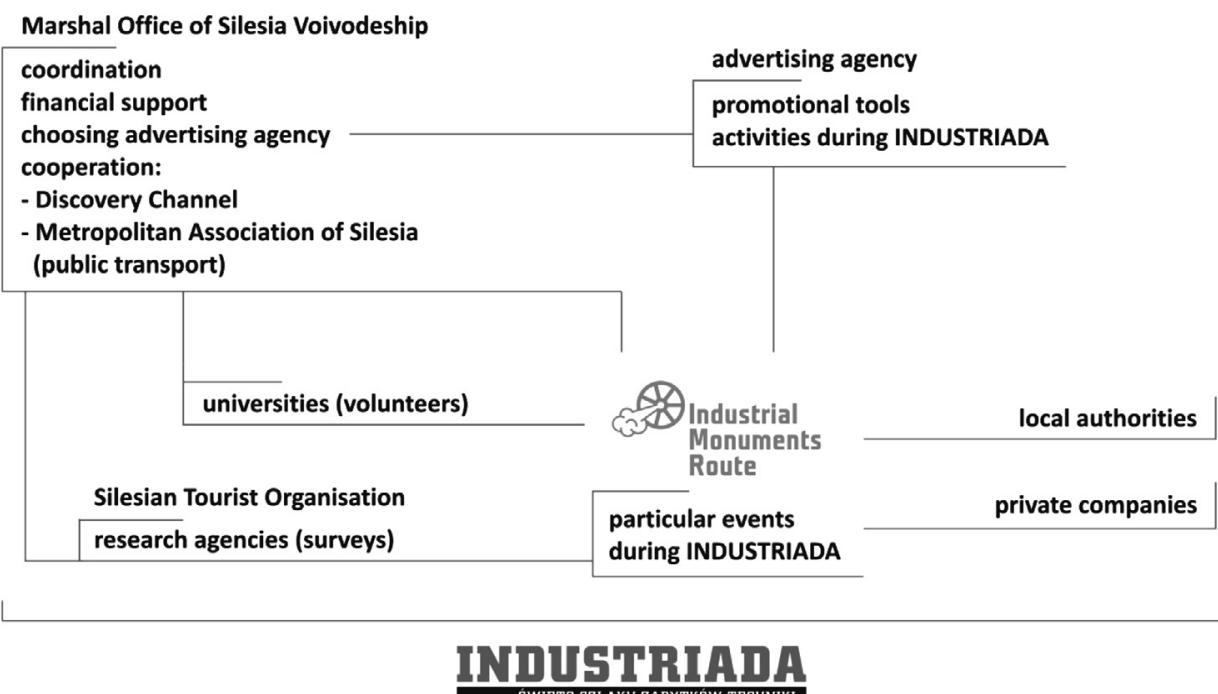

Source: data of Silesian Voivodeship Marshall Office

As it has been indicated in Figure 2, the owners and managers of the sites together with local authorities are responsible for the organization and running of the events at the Industrial Monuments Route during "Industriada". Therefore, the global amount of expenditure which was assigned for the organization of the Route's feast is undoubtedly greater and the ultimate budget should be estimated at around 3.5 million PLN.

Year by year, the festival attracts more and more public mass media interest. The first year generated 261 publicity materials, and in case of the third year the number reached 711 publications, most of which was published on the Internet (563). 100\% of them were positive or neutral. According to Press-Service Media Monitoring, the advertising equivalent amounted to 3 million PLN (Hajduga \& Staszewska, 2013). 
After three successful years of INDUSTRIADA, it is possible to conclude that it is not only about increasing the popularity of the Route and attractions, but it has become one of the most important tourism product of the Province itself which helped to increase competitiveness and perception of the Province, cities, the Route and attractions.

\section{Conclusion}

Within the tourism literature, an increasingly systematic research approach has been adopted towards the concept of destination competitiveness. Destination competitiveness and its enhancement is a complicated task as it involves many entities of different kinds. It is also interlinked with competitiveness of local tourism companies, attractions, and products. Analysing destination competitiveness at the regional level seems to be a very challenging task since it involves more perspectives and stakeholders. Common approaches available in the literature provide only hints about individual perspectives, such as regional competitiveness, individual tourism products competitiveness, competitiveness of tourism companies and facilities. However, those perspectives are mutually interlinked and individual levels influence each other. In such a situation the networking approach seems to be the most appropriate solution. And yet, a simple adaptation of the whole network approach or the egocentric network approach will also not give the full picture. The presented case study gives an example of the parallel use of both approaches to network analysis.

The positive link between competitiveness of a destination (the Silesian Province), of a product (The Industrial Monuments Route) and attractions can be observed on the basis of the presented example. The creation of the Route and its reasonable development and promotion enhanced the image of the region and introduced isolated attractions onto regional, national and international tourism market as important parts of attractiveness of the region. The establishment of the Industrial Monuments Route and organization of the promotional festival - "Industriada" - seem to be the activities which effectively popularize the industrial heritage of the Silesian Voivodeship. Still the process of competitiveness enhancement has not finished. Other actions should be undertaken to increase the intensity of tourism movement and to develop business activities connected with the Route. In that context one might state that an initial success should not be a reason for accepting the product as finished and successful. On the contrary, the network approach suggests that the network should evolve all the time to meet new requirements of such a dynamically changing environment. Another reason of this necessity of the ongoing evolution is connected with internal conditions. With the initial success also the expectations of the network members are changing. More and more operators of attractions embraced by the Route connect their market success with the successful operation of the Route. Moreover, stagnation is not acceptable for the regional authorities that created the Route. However, the network development is not a perpetuum mobile and is not going to happen just on the basis of the success achieved in the past and purposeful actions should be undertaken. 
This is one of the biggest challenges as these actions need new ideas and attitudes, sometimes also new solutions with respect to the organization and the structure of the network which are currently perceived as working properly.

The presented case study is only an illustration of the phenomenon. In addition, it should point out further direction of studies. Obviously, different destinations are characterized by different links between individual stakeholders. Even the list of stakeholders in the particular destinations would be different. That is why the main objective of prospective research should be the development of a more coherent theory of stakeholders in tourism destinations.

There are many directions of future research on this topic; for example, the research connected with a comparison of the Industrial Monuments Route with existing networks in England, in Germany or in other countries. Moreover, relations linking stakeholders in different cases could be radically different. Also very interesting research could concern studies of the network of stakeholders in relation to their behaviour or determination of their motivation.

\section{Literature}

d'Angella, F., De Carlo, M., \& Sainaghi, R. (2010). Archetypes of destination governance: a comparison of international destinations. Tourism Review, 65(4), 61-73.

Backes, P. (2008). A network of the industrial heritage covers Europe ERIH, European route of Industrial Heritage, EUBULDIT - Buildings Telling European History, 1-2.

Beritelli, P., Begier, T., \& Laesser, C. (2007). Destination governance: Using corporate governance theories as a foundation for effective destination management. Journal of Travel Research, 46(1), 96-107.

Bornhorst, T., Ritchie, J. R. B., \& Sheehan, L. (2010). Determinants of tourism success for DMOs \& destinations: An empirical examination of stakeholders' perspectives. Tourism Management, $31(5), 572-589$.

Chung, K. K., Hossain, L., \& Davis, J. (2005, November). Exploring sociocentric and egocentric approaches for social network analysis. In Proceedings of the 2 nd international conference on knowledge management in Asia Pacific.

Buhalis, D. (2000). Marketing the competitive destination of the future. Tourism Management, 21(1), 97-116.

Dwyer L., \& Kim C. (2003). Destination Competitiveness: Determinants and Indicators. Current Issues in Tourism, 6(5), 369-414.

Eisenhardt, K. M. (1989). Building theories from case study research. The Academy of Management Review, 14(4), 532-550.

Emirbayer, M. (1997). Manifesto for a Relational Sociology. The American Journal of Sociology, 103(2), 281-317.

Flagestad, A., \& Hope C.A., (2001). Strategic Success in Winter Sports Destinations: A Sustainable Value Creation Perspective. Tourism Management, 22(4), 445-461.

Freeman, R. E. (1984). Strategic management: A stakeholder approach. Boston: Pitman.

von Friedrichs Grangsjo, Y. (2003). Destination networking: Co-opetition in peripheral surroundings. International Journal of Physical Distribution E Logistics Management, 33(5), 427-448. 
Fyall, A., \& Garrod, B. (2005). Tourism Marketing. A Collaborative Approach. Clevedon: Channel View Publications.

Fyall, A., Garrod, B., \& Wang, Y. (2012). Destination collaboration: A critical review of theoretical approaches to a multi-dimensional phenomenon. Journal of Destination Marketing $\mathcal{E}$ Management, 1(1), 10-26.

Fyall, A., Garrod ,B. ,\& Tosun, C. (2006). Destination marketing: A framework for future research. In M. Kozak, \& L. Andreu (Eds.), Progress in tourism marketing (pp. 75-86). Oxford: Elsevier.

Freeman, R. E. (1984). Strategic management: A stakeholder approach (Vol. 1). Boston: Pitman

Go, F.M., \& Govers, R. (2000). Integrated quality management for tourist destinations: a European perspective on achieving competitiveness. Tourism Management, 21 (1), 79-88.

Hajduga A., \& Staszewska, A. (2013). Industrial heritage tourism - the case study of Silesian Voivodeship. In New Trends In Tourism Management and Marketing, 113-114.

Hall, M. C. (1999). Rethinking collaboration and partnership: a public policy perspective. Journal of Sustainable Tourism, 7(3\&4), 274-289.

Jamal, T. B., \& Getz, D. (1995). Collaboration theory and community tourism planning. Annals of Tourism Research, 22(1), 186-204.

Kilduff, M. \& Tsai, W. (2003). Social networks and organizations. Thousands Oaks: Sage.

Manente, M., \& Minghetti, V. (2006). Destination management organizations and actors. In D.Buhalis, \& C. Costa (Eds.), Tourism business frontiers: Consumers, products and industry (pp. 228-237).Oxford: Elsevier Butterworth-Heinemann.

Middleton, V. T., \& Hawkins, R. (1998). Sustainable tourism. Routledge: Oxford.

Ritchie, J. R. B, \& Crouch, G. I. (2005). The competitive destination: A sustainable tourism perspective. London: CABI.

Roberts, L., \& Simpson, F. (1999). Developing partnership approaches to tourism in Central and Eastern Europe. Journal of Sustainable Tourism, 7(3-4), 314-330.

Scott, N., Cooper, C., \& Baggio, R. (2007). Use of network analysis in tourism research. Paper presented during the International Conference Advances in Tourism Marketing. Destination and Event Marketing: Managing Networks, Valencia 10-12.09.2007.

Roberts, L., \& Simpson, F. (1999). Developing partnership approaches to tourism in Central and Eastern Europe. Journal of Sustainable Tourism, 7(3\&4), 14-330.

Sautter, E. T. \& Leisen, B. (1999). Managing stakeholders: A tourism planning model. Annals of Tourism Research, 26(2), 312-328.

Simpson, K., \& Bretherton, P. (2004) Co-operative business practices in the competitive leisure destination: lessons from the wine tourism industry in New Zealand. Managing Leisure, 9(2), 110-119.

Vanhove, N. (2005). The Economics of Tourism Destination. Elsevier: Butter.

Wang, Y., \& Xiang, Z. (2007). Toward a theoretical framework of collaborative marketing. Journal of Travel Research, 46(1), 75-85.

Williams, K. \& Durrance, C. (2008). Social networks and social capital: Rethinking theory in community informatics. In K. Williams (Ed.) eChicago 2007. Proceedings of the inaugural eChicago symposium held at Dominican University, River Forest, Illinois, April 20, 2007. Chicago: Dominican University.

UNWTO, (2010). Joining forces. Collaborative processes for sustainable and competitive tourism. Madrid: UNWTO.

UNWTO (2011). Handbook on tourism product development. Madrid: UNWTO.

Yin, R. (1984). Case study research. Beverly Hills, Calif.: Sage Publications. 
Ysa, T., Curtó, F. \& Esteve, M. (2009). Networks never walk alone: The management of network portfolios. University Ramon Llull working paper.

Żabińska, T., \& Maciąg, J. (2013). Networking in tourism. Theory versus practice of its functioning in Poland. In J. Wyrzykowski, \& J. Marak (Eds.), Regional tourism product. Theory and practice. Wrocław: University of Business in Wrocław.

Żemła, M. (2008). Failures in building partnership for success in the competitive market: The case study of Polish ski resorts. Managing Global Transitions, 6(4), 421-444. 